\title{
Application of RT-PCR for Indexing Avocado Sunblotch Viroid
}

\author{
R. J. Schnell, USDA-ARS, National Germplasm Repository, 13601 Old Cutler Rd., Miami, FL 33158; D. N. Kuhn, \\ Florida International University, Department of Biological Sciences, Miami 33199; and C. M. Ronning and D. \\ Harkins, USDA-ARS, National Germplasm Repository, 13601 Old Cutler Rd., Miami, FL 33158
}

\begin{abstract}
Schnell, R. J., Kuhn, D. N., Ronning, C. M., and Harkins, D. 1997. Application of RT-PCR for indexing avocado sunblotch viroid. Plant Dis. 81:1023-1026.

A method for the routine detection of avocado sunblotch viroid (ASBVd) in nucleic acid extracts of infected avocado tissues by reverse transcription-polymerase chain reaction (RT-PCR) was developed using ASBVd-specific primers. Amplified cDNA products were analyzed by electrophoresis on nondenaturing $6 \%$ polyacrylamide slab gels. The size of the major RT-PCR product from ASBVd-infected tissue was estimated to be $250 \mathrm{bp}$. This product was absent from amplified extracts of uninfected tissue. The amplification product from ASBVd was sequenced by the dideoxynucleotide chain termination method, and the sequence was over $97 \%$ identical to the published sequence. The RT-PCR assay is sensitive enough to allow viroid detection without requiring large amounts of tissue, highly purified ASBVd, or molecular hybridization.
\end{abstract}

Sunblotch disease of avocado was first described by Horne and Parker (7). The disease produces sunken yellow or red discoloration on the fruit, which severely decrease its marketability. The causal agent, avocado sunblotch viroid (ASBVd), was established by Palukaitis et al. (11) as an infective single-stranded circular RNA molecule of 247 nucleotides. ASBVd is transmitted mechanically, through pollen, seed, and by root-grafting; no known insect vector has been identified. ASBVd can be transmitted to other members of the Lauraceae by graft inoculation. A bioassay has been developed; however, infected trees may remain asymptomatic for prolonged periods, making detection of the pathogen difficult (5).

Sequence variation has been demonstrated, and most variation is caused by $\mathrm{U}$ A exchanges. The variants ranged from 246 to 251 nucleotides $(10,12)$. Self-cleavage has also been demonstrated for ASBVd (8), and differences in symptoms have been associated with changes in RNA sequence (13).

The ability to selectively amplify RNA using reverse transcriptase and the polymerase chain reaction (RT-PCR) has proven valuable in detecting viroid-infected plants. The technique was adapted for the detection of apple skin scar viroid (ASSVd), dapple apple viroid (DAVd), citrus exocortis viroid (CEVd), cachexia viroid $(\mathrm{CCaVd})(6,15)$, and ASBVd (13).

Corresponding author: R. J. Schnell

E-mail: miars@ars-grm.gov

Accepted for publication 20 May 1997.

Publication no. D-1997-0630-01R

(C) 1997 The American Phytopathological Society
Detection of viroids using RT-PCR has the advantage of greater sensitivity than techniques based on polyacrylamide gel electrophoresis (PAGE), and the time required for the assay is significantly reduced.

Our objectives were to design primers specific for ASBVd and to develop an RTPCR assay to detect the pathogen in avocado total nucleic acid extracts. Additional goals were to use PCR to determine the optimum concentration of avocado total nucleic acids needed for ASBVd detection and to confirm previous reports of titer differences between tissue types and difficulties associated with detection (13).

\section{MATERIALS AND METHODS}

Plant materials. All tissue samples were collected from plants maintained at the National Germplasm Repository (NGR), Miami, Florida, and from local farms in the Homestead, Florida, area.

The positive controls were avocado trees that expressed the typical disease symptom of large yellow blotches on the fruit for the past 5 years. The negative controls were avocado trees from an area of the NGR where symptoms of sunblotch have not been observed on any plants. The trees were not bioassayed for the viroid. All 429 avocado trees at the NGR were assayed using ASBVd-specific RT-PCR.

Extraction. The extraction procedure was essentially that described by Hadidi and Yang (6). Young leaf, old leaf, and flower tissue samples were ground to a fine powder in liquid nitrogen to which $4 \mathrm{ml}$ of extraction buffer per $\mathrm{g}$ of fresh weight tissue was added $(0.1 \mathrm{M}$ Tris- $\mathrm{HCl}, \mathrm{pH} 8.0$, $1.5 \mathrm{M} \mathrm{NaCl}, 0.5 \%$ 2-mercaptoethanol, and $5 \%$ [wt/vol] polyvinylpolypyrrolidone) with continued grinding. The slurry was stirred for $10 \mathrm{~min}$ before extracting with an equal volume of $1.0 \mathrm{M}$ Tris- $\mathrm{HCl}$ buffered phenol, $\mathrm{pH} 7.4$, containing $0.1 \%$ 8-hydroxyquinoline, and subsequently stirred for $10 \mathrm{~min}$. The samples were further extracted with 2 volumes of chloroform, then centrifuged at $7,650 \times g$ for $10 \mathrm{~min}$ at $4^{\circ} \mathrm{C}$. Nucleic acids were precipitated from the aqueous phase with $1 / 10$ volume of $3 \mathrm{M}$

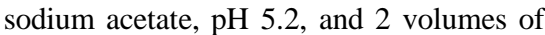
ice cold absolute ethanol. The pellets were air-dried and resuspended in $1 \mathrm{ml}$ of $1 \mathrm{M}$ $\mathrm{NaCl}$ and centrifuged at $1,600 \times g$ for 5 min at $4^{\circ} \mathrm{C}$ in a microcentrifuge. Nucleic acids were again precipitated from the supernatant with $1 / 10$ volume of $20 \mathrm{mM}$ EDTA and an equal volume ice cold absolute ethanol. The pellet was air-dried, then resuspended in $500 \mu \mathrm{l}$ of $1.0 \mathrm{M} \mathrm{NaCl}$. The suspension was centrifuged as before for $10 \mathrm{~min}$, and the supernatant was transferred to a fresh microcentrifuge tube to which $1 / 10$ volume of $3 \mathrm{M}$ sodium acetate, $\mathrm{pH}$ 5.2, and 2 volumes ice cold ethanol were added. Samples were incubated at $-70^{\circ} \mathrm{C}$ for $1 \mathrm{~h}$ or at $-20^{\circ} \mathrm{C}$ overnight, then centrifuged at $16,000 \times g$ for $20 \mathrm{~min}$ at $4^{\circ} \mathrm{C}$. The resulting pellet was vacuum dried, and the pellets were dissolved in 10 $\mathrm{ml}$ of TE (Tris-EDTA), $\mathrm{pH}$ 8.0. This extract was either purified by column chromatography (see below) or used as a crude fraction for the subsequent RT-PCR reactions.

Column chromatography. Nucleic acids were purified by the addition of $1 \mathrm{~g}$ of DEAE cellulose resin to each of the dissolved pellets, and the samples were gently mixed for $15 \mathrm{~min}$ at $25^{\circ} \mathrm{C}$. The mixtures were then centrifuged at $3,000 \times g$ for 5 $\mathrm{min}$, and the pellets were resuspended in $10 \mathrm{ml}$ of $0.2 \mathrm{M} \mathrm{NaCl}$ in TAE (TRIS-sodium acetate-EDTA), mixing gently for 15 $\min$ at $25^{\circ} \mathrm{C}$. This step was repeated two more times, and the final pellet was then resuspended in $10 \mathrm{ml}$ of $0.2 \mathrm{M} \mathrm{NaCl}$. The samples were transferred to $1 \times 20 \mathrm{~cm}$ columns (Kontes Glass, Vineland, NJ) and allowed to settle. The columns were washed with $15 \mathrm{ml}$ of $0.2 \mathrm{M} \mathrm{NaCl}$, and the UV absorbance of the eluate was scanned between 200 and $300 \mathrm{~nm}$ with a spectrophotometer. An additional $15 \mathrm{ml}$ of $0.2 \mathrm{M} \mathrm{NaCl}$ was dripped through the columns, and the eluate was collected and scanned until the UV absorbance at 260 $\mathrm{nm}$ was zero. Viroid RNA was eluted from the column with the addition of 12 $\mathrm{ml}$ of $1.5 \mathrm{M} \mathrm{NaCl}$ in TAE. Three volumes of cold absolute ethanol were added to the fractions to precipitate nucleic acids after storage at $-70^{\circ} \mathrm{C}$ for $1 \mathrm{~h}$. The nu- 
cleic acids were pelleted by centrifugation at $10,000 \times g$ for $20 \mathrm{~min}$ at $4^{\circ} \mathrm{C}$, and pellets were washed with $70 \%$ ethanol, vacuum dried, and dissolved in 200 $\mu \mathrm{l}$ of sterile TE, $\mathrm{pH}$ 8.0. Nucleic acid concentrations were determined by UV absorbance at $260 \mathrm{~nm}$.
cDNA synthesis. First strand cDNA was synthesized from $1 \mu \mathrm{l}$ of sample containing various concentrations of nucleic acids (0.001 to $30 \mathrm{ng}$ ) added to a buffer containing $1 \times$ first strand buffer $(50 \mathrm{mM}$ Tris $\mathrm{HCl}, \mathrm{pH} 8.3,75 \mathrm{mM} \mathrm{KCl}, 3 \mathrm{mM} \mathrm{MgCl}$ [Gibco BRL, Gaithersburg MD]), $0.01 \mathrm{M}$
DTT (Gibco BRL), and $3 \mu \mathrm{g}$ of forward primer (5'-AAGTCGAAACTCAGAGTCGG-3', synthesized on a Model 391 DNA Synthesizer [Applied Biosystems, Foster City, CA]) complementary to ASBVd nucleotides 68 to 87 in the upper conserved region (2). The final volume was adjusted

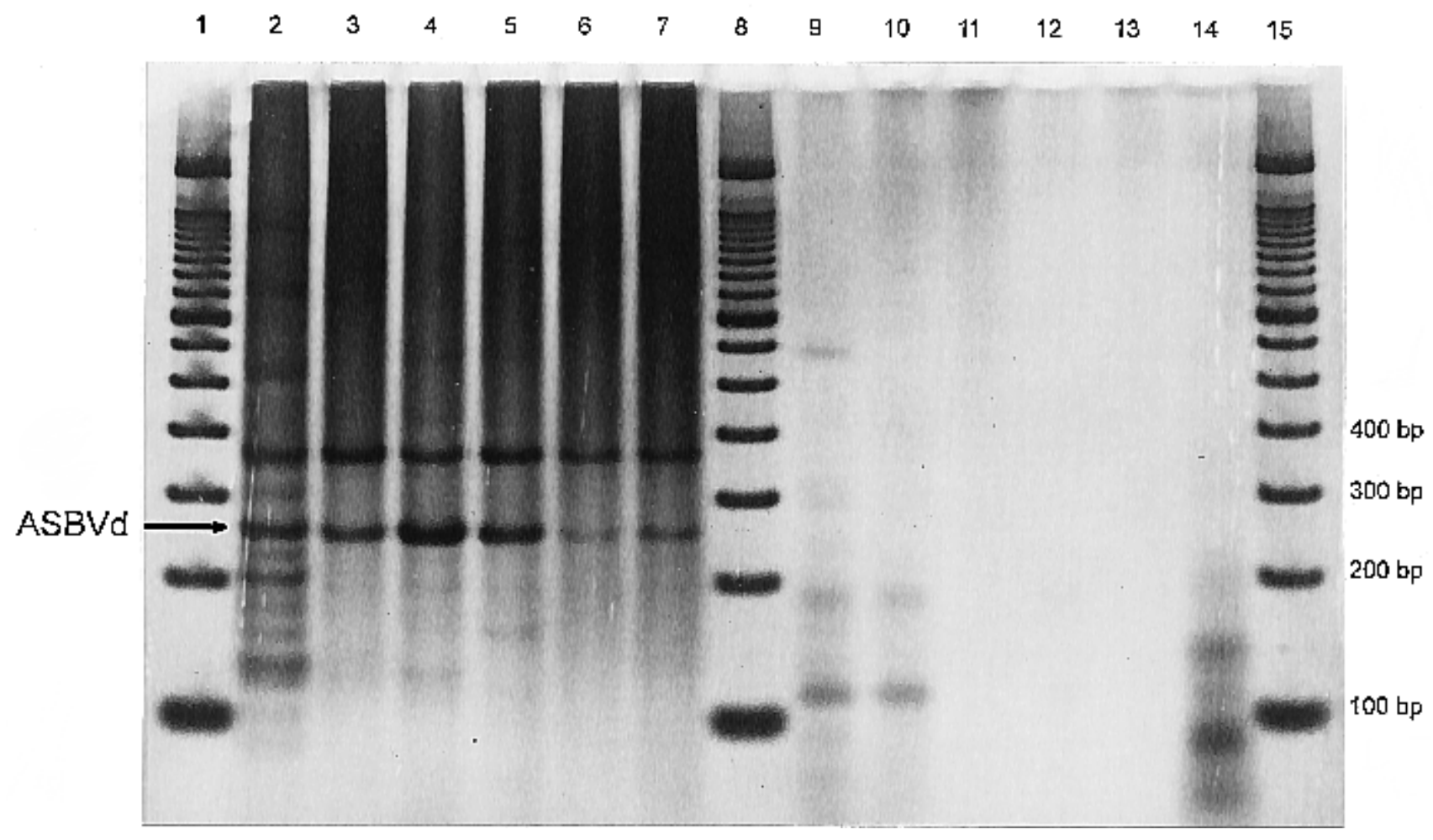

Fig. 1. Polyacrylamide gel electrophoretic analysis of reverse transcription-polymerase chain reaction (RT-PCR)-amplified avocado sunblotch viroid (ASBVd) cDNA from total nucleic acids from infected accessions Progresso Late, Wilson Popenoe, Aycock Red\#3, Vero Beach\#15, Vero Beach, and Aycock Red\#19 (lanes 2 to 7), noninfected avocado accessions Morocco\#43, Romani\#1, Tito Perla, and Vero Beach SE2 (lanes 9 to 14), and species of two related genera, Cinnamomum sp. and Laurus nobilis (lanes 13 and 14). Lanes 1, 8, and 15 are a 100-bp ladder.

1

J02020.Frg tttattagaa caagaagtga ggatatgatt aaactttgtt tgacgaacc Asbvmiami.Frg tttattagaa caagaagtga ggatatgaWt aaacttgtt tgacgaaacc

51

J02020.Frg aggtctgttc cgactttccg actctgagtt tcgacttgtg agagaaggag Asbvmiami.Frg aggtctgttc cgacttt....................

101

J02020.Frg gagtcgtggt gaacttttat taaaaaatt algttcactcg tcttcalatct Asbvmiami.Frg ....cgtggt gaacttttat taaaaaatt Tgttcactcg tcttcGatct

J02020.Frg cttgatcact tcgtctcttc agggaaagat gggaagaaca ctgatgagtc Asbvmiami.Frg cttgatcact tcgtctcttc agggaaagat gggaagaaca ctgatgagtc

\section{J02020.Frg tcgcaaggtt tactcctcta tcttcattgt ttttttacaa aatcttg Asbvmiami.Frg tcgcaaggtt tactcctcta tcttcattgt ttttttacaa aatcttg}

Fig. 2. Comparison of sequence homology between published avocado sunblotch viroid (ASBVd) sequence (GenBank accession J02020) and the reverse transcription-polymerase chain reaction (RT-PCR)-amplified ASBVd cDNA from the Donaldson accession. ... represents primer sequences. Boxed area represents sequence variation. W represents a position at which either base A or T was present. 
to $30 \mu \mathrm{l}$ with water. The primer was annealed to the viroid template by incubation at $100^{\circ} \mathrm{C}$ for $5 \mathrm{~min}$, placed on ice for 2 min, then allowed to stand at room temperature for $1 \mathrm{~h}$. Twenty $\mu \mathrm{l}$ of a cDNA reaction mixture containing $1 \times$ first strand buffer, $1.25 \mathrm{mM}$ of each dNTP, $75 \mathrm{mM} \beta$ mercaptoethanol, 40 units RNasin (Promega Corporation, Madison, WI), and 400 units M-MLV Reverse Transcriptase (Gibco BRL) was then added to each annealing reaction and adjusted to a total reaction volume of $50 \mu \mathrm{l}$ with water. The reactions were incubated at $42^{\circ} \mathrm{C}$ for $2.5 \mathrm{~h}$.

PCR amplification. Five- $\mu$ l aliquots of the first strand cDNA synthesis reactions were added to $45 \mu \mathrm{l}$ of a PCR reaction mixture containing $1 \times$ PCR buffer $(10 \mathrm{mM}$ Tris- $\mathrm{HCl}, \mathrm{pH} 8.3,50 \mathrm{mM} \mathrm{KCl}, 1.5 \mathrm{mM}$ $\mathrm{MgCl}_{2}, 0.001 \%$ [wt/vol] gelatin), $200 \mu \mathrm{M}$ each dNTP, 2.5 units Amplitaq DNA Polymerase (Perkin Elmer Corporation, Norwalk, CT), $2 \mu \mathrm{M}$ forward primer, and $1 \mu \mathrm{M}$ of reverse primer (5'-GTGAGAGAAGGAGGAGT-3', synthesized on a Model 391 DNA synthesizer [Applied Biosystems]) homologous to ASBVd nucleotides 88 to 104 in the upper conserved region (2). The amplifications were performed in a DNA Thermal Cycler 480 (Perkin Elmer) for 40 cycles under the following conditions: $1 \mathrm{~min}$ at $94^{\circ} \mathrm{C}, 2 \mathrm{~min}$ at $55^{\circ} \mathrm{C}$, and 3 min at $72^{\circ} \mathrm{C}$, with a final extension of 4 min at $72^{\circ} \mathrm{C}$.

Gel electrophoresis. Amplified cDNA products were analyzed by electrophoresis either on nondenaturing $6 \%$ polyacrylamide slab gels in $1 \times \mathrm{TBE}$, and silver stained to visualize the bands (14), or in $2 \%$ agarose gels in $1 \times \mathrm{TBE}$ and visualized with ethidium bromide.

Cycle sequencing. PCR products of approximately $250 \mathrm{bp}$ were excised from low-melting-point agarose gels, extracted by following the Magic PCR Purification Kit protocol (Promega, Madison, WI), and sequenced directly. Both forward and reverse primers were end-labeled with $\gamma^{32} \mathrm{P}$ ATP $(6,000 \mathrm{Ci} / \mathrm{mmol}$; NEN Dupont, Boston, MA) using T4 polynucleotide kinase (New England Biolabs, Beverly, MA). Two amplification reactions were performed using one of the end-labeled primers and $100 \mathrm{fmol}$ of the cDNA template. The reaction mixtures were subjected to 45 cycles of $95^{\circ} \mathrm{C}$ for $30 \mathrm{~s}, 42^{\circ} \mathrm{C}$ for $30 \mathrm{~s}$, and $70^{\circ} \mathrm{C}$ for $1 \mathrm{~min}$ (Perkin-Elmer Cetus).

The fragments were separated on an $8 \%$ polyacrylamide sequencing gel and exposed to X-ray film for visualization and documentation. DNA sequencing was also performed using an Applied Biosystems International (ABI) 373A DNA sequencer using the Taq DyeDeoxy Terminator Cycle Sequencing Kit (Applied Biosystems).

\section{RESULTS AND DISCUSSION}

Column chromatography was used initially to isolate nucleic acids for the RTPCR reaction. In Figure 1, lanes 2 through
7 are samples of column chromatography purified nucleic acids from plants known to be infected with the viroid. The RT-PCR resulted in the amplification of the approximately 250 -bp product. Amplification products were not observed in lanes 9 to 12 , representing column chromatography purified nucleic acids from noninfected trees, or in lanes 13 and 14, which represent accessions of the related genera Cinnamomum and Laurus. Column chromatography purification is a difficult and time-consuming extraction procedure; however, RT-PCR of column purified nucleic acids produces few artifacts.

To verify that the amplification product was ASBVd, bands of approximately 250 bp were excised from the gel, purified, and subjected to cycle sequencing. The partial sequence of the amplified fragment from the accession Donaldson was compared with the GenBank database using the BLAST algorithm (1). The partial sequence of the amplified fragment and the sequence of ASBVd (GenBank accession
J02020) differed with two base substitutions (131 and 146) and one base modulation (29) (Fig. 2). Thus, the RT-PCR product is over $97 \%$ identical to this variant of ASBVd.

Amplification of total nucleic acids without using column chromatography purification has proven effective in the detection of ASBVd. Samples amplified with both column chromatography purified and crude nucleic acid extracts are illustrated in Figure 3. Lanes 2, 4, and 6 are amplifications from purified nucleic acid extracts, while lanes 3,5 , and 7 are amplifications from crude extracts of the infected cultivars Aycock Red\#19, Progresso Late, and Lima Late, respectively. Lanes 9 and 10 are amplifications from purified and crude nucleic acids from the negative control Dade.

The ability to detect ASBVd in symptomless old leaves, young leaves, and flowers is demonstrated in Figure 4 using RT-PCR products from crude samples of the symptomless infected cultivars Lima

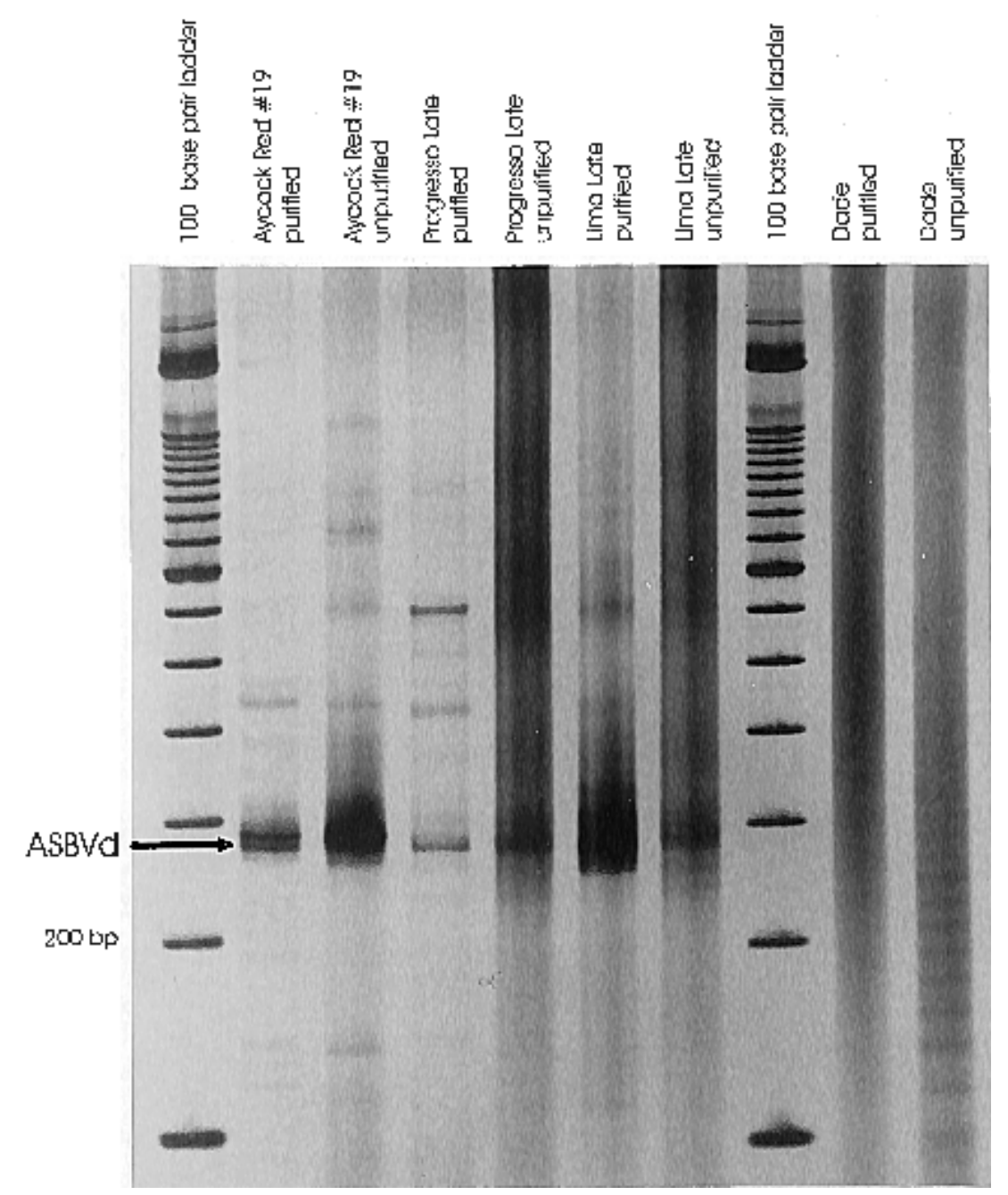

Fig. 3. Polyacrylamide gel electrophoretic analysis of reverse transcription-polymerase chain reaction (RT-PCR)-amplified avocado sunblotch viroid (ASBVd) cDNA from column chromatography purified and crude extracts of total nucleic acids from infected accessions Aycock Red\#19 (lanes 2 and 3), Progresso Late (lanes 4 and 5), and Lima Late (lanes 6 and 7), and from the noninfected avocado accession Dade (lanes 9 and 10). Lanes 1 and 8 are a 100-bp ladder. 


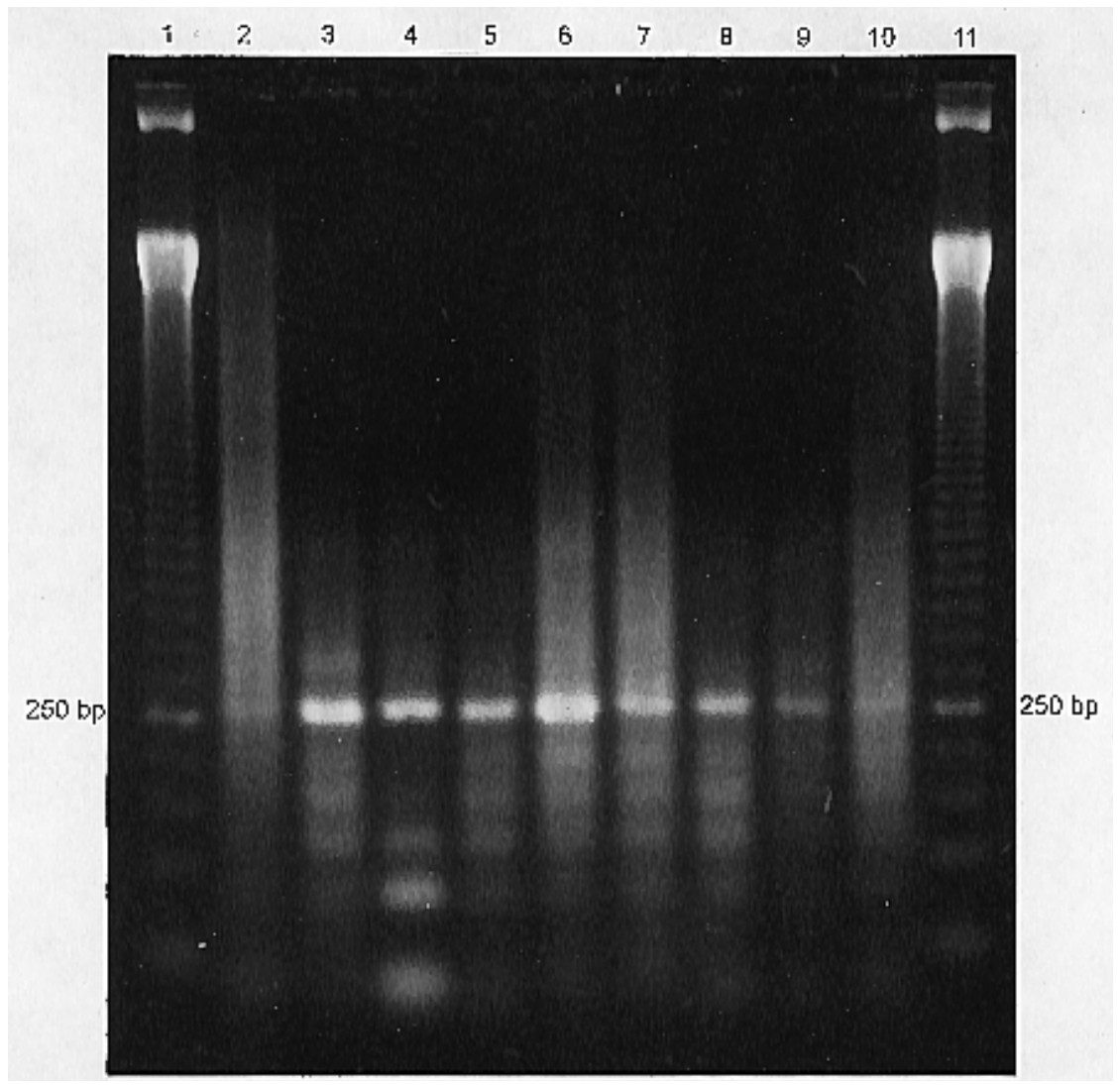

Fig. 4. Two percent agarose gel electrophoretic analysis of reverse transcription-polymerase chain reaction (RT-PCR)-amplified avocado sunblotch viroid (ASBVd) cDNA synthesized from nonsymptomatic tissues of ASBVd-infected avocado accessions. Lanes 1 and 11, 50-bp ladder; lanes 2 to 4, Lima Late, young leaf, old leaf, and flower, respectively; lanes 5 to 7, Progresso Late, young leaf, old leaf, and flower, respectively; and lanes 8 to 10, Vero Beach, young leaf, old leaf, and flower, respectively.

Late, Progresso Late, and Vero Beach, respectively. This finding confirms a previous report that ASBVd could be difficult to detect using sPAGE in some symptomless tissues but was detectable using RTPCR (13). Amplification using these specific primers detected ASBVd in all cases except for young leaves of Lima Late. Titers of the viroid have been reported to be higher in flowers than in other tissues $(3,9)$; however, our data did not support those findings. ASBVd was detectable using only $1.0 \mathrm{ng}$ of total nucleic acids in the RT-PCR reaction.

By using crude nucleic acid extracts, all of the 429 avocado trees at the NGR were screened for ASBVd using the RT-PCR assay. The results indicated that 81 trees were positive for the viroid. These 81 trees were then assayed again. Both reactions detected the viroid in 69 trees $(85.2 \%)$. The remaining 12 trees $(14.8 \%)$ were positive in only one of the two reactions. The failure to detect ASBVd in these 12 reactions may be caused by inhibitors, carried over in non-column-purified nucleic acids, which prevented ASBVd from being amplified. Development of an internal control is in progress which should allow identification of false negative reactions.

The use of a simplified extraction procedure combined with ASBVd-specific RT-PCR assay resulted in a simple, fast, and accurate detection of ASBVd. The ability to repeatedly detect ASBVdpositive trees from crude nucleic acid extracts was estimated to be accurate for $85 \%(\mathrm{SE}= \pm 3.95)$ of the assays. This detection rate is similar to bioassays carried out in controlled-temperature greenhouses $\left(30 / 28^{\circ} \mathrm{C}\right.$ day/night) and much higher than in bioassays where the temperature was lower $\left(20 / 18^{\circ} \mathrm{C}\right.$ day/night $)$ or not controlled (4). With the elevated temperature, the bioassay required 8 months to complete; and under the cooler temperatures, it required more than 1 year. Detection of ASBVd in crude extracts from field-grown plants as demonstrated here can be accomplished in a few days.
This procedure has already been effectively used to stop nonsymptomatic ASBVd-infected germplasm from being distributed. We are currently using the ASBVd-specific RT-PCR assay for detection of ASBVd in commercial groves in Florida and are investigating sequence variation occurring in these groves and in the germplasm collection.

\section{LITERATURE CITED}

1. Altschul, S. F., Gish, W., Miller, W., Myers, E. W., and Lipman, D. J. 1990. Basic Local Alignment Search Tool. J. Mol. Biol 215:403.

2. Bar-Joseph, M., Segev, D., Twizer, S., and Rosner, A. 1985. Detection of Avocado Sunblotch Viroid by hybridization with synthetic oligonucleotide probes. J. Virol. Methods 10:69-73.

3. da Graca, J. V., and Moon, T. E. 1983. Detection of avocado sunblotch viroid in flower buds by polyacrylamide gel electrophoresis Phytopathol. Z. 108:267-280.

4. da Graca, J. V., and van Vuuren, S. P. 1981 Use of high temperature to increase the rate of avocado sunblotch symptom development in indicator seedlings. Plant Dis. 65:46-47.

5. Dale, J. L., Symons, R. H., and Allen, R. N 1982. Avocado sunblotch viroid. CMI/AAB Descriptions of Plant Viruses. No. 254

6. Hadidi, A., and Yang, X. 1990. Detection of pome fruit viroids by enzymatic cDNA amplification. J. Virol. Methods 30:261-270.

7. Horne, W. T., and Parker, E. R. 1931. The avocado disease called sunblotch. Phytopathology 21:235-238.

8. Hutchins, C. J., Rathjen, P. D., Forster, A. C., and Symons, R. H. 1986. Self-cleavage of plus and minus RNA transcripts of avocado sunblotch viroid. Nucleic Acids Res. 14:3627-3640.

9. Marcos, J. F., and Flores, R. 1992. Characterization of RNAs specific to Avocado Sunblotch Viroid by a cell-free system from infected avocado leaves. Virology 186:481-488.

10. Pallas, V., Garcia-Luque, I., Domingo, E., and Flores, R. 1988 Sequence variability in avocado sunblotch viroid (ASBVD). Nucleic Acids Res. 16:9864.

11. Palukaitis, P., Hatta, T., Alexander, D-McE., and Symons, R. H. 1979. Characterization of a viroid associated with avocado sunblotch disease. Virology 173:352-356.

12. Rakowski, A. G., and Symons, R. H. 1989. Comparative sequence studies of variants of avocado sunblotch viroid. Virology 173:352356.

13. Semancik, J. S., and Szychowski, J. A. 1994 Avocado sunblotch disease: A persistent vi roid infection in which variants are associated with differential symptoms. J. Gen. Virol. 75:1543-1549.

14. Singh, R. P., and Boucher, A. 1987. Electrophoretic separation of a severe from mild strains of potato spindle tuber viroid. Phytopathology 77:1588-1591

15. Yang, X., Hadidi, A., and Garnsey, S. M 1992. Enzymatic cDNA amplification of citrus exocortis and cachexia viroids from infected citrus hosts. Phytopathology 82:279285. 